Türkiye Jeoloji Bülteni
Geological Bulletin of Turkey
$60(2017) 331-346$
doi:10.25288/tjb.325395

\title{
Belek Kıyısı (Antalya) İçin Kıyı Kenar Çizgisinin Önemi
}

Importance of Shoreline for the Belek Coast (Antalya, Turkey)

\section{Mehmet Özçelik}

\section{Süleyman Demirel Üniversitesi, Mühendislik Fakültesi, Jeoloji Müh. Böl. 32260, Isparta}

Geliş/Received : 24.03.2017 • Düzeltilmiş Metin Geliş/Revised Manuscript Received : 13.06.2017 • Kabul/Accepted : 16.06.2017 • Bask1/Printed : 01.08 .2017 Araştırma Makalesi/Research Article Türkije Jeol. Bül. / Geol. Bull. Turkey

Öz: Türkiye'nin en önemli turizm merkezi olan Antalya'nın kıyılarının uzunluğu yaklaşık 640 km’dir. Kıyı bölgesi hızlı bir şekilde yapılaşmadan dolayı tahrip edilmiştir. Belek kıyıları flora ve fauna türleri için uygun habitatlar oluşturmakta ve mikro klimatik özellikleri nedeniyle tatil ve dinlenme olanakları sağlayan önemli turizm alanıdır. Belek kıyısı, kumulların biçimlendirdiği 29 km kıyısal alana sahiptir. Az bulunan flora ve faunanın yaşam ortamıdır. Gün geçtikçe gelişen turizm faaliyetleri Belek kıyılarını daha fazla cazip kılmaktadır. Kıyı Kanununa göre kıyı çizgisi ile kıyı kenar çizgisi arasındaki alan kıyı olarak tanımlanmaktadır. Günümüzde kıyı alanlarından daha fazla yararlanmak için beșeri (antropojen) kökenli müdahaleler yapılmaktadır. Bu tip alanlarda Kıyı Kenar Çizgisinin yeniden belirlenmesi ile farklı Kıyı Kenar Çizgisinin oluşmasına neden olmaktadır. Kıyılar kamu kullanımında olup, özel mülkiyet alanları bulunmamaktadır. Zamanla kıyıda yapılan müdahaleler sonucunda kıyı kenar çizgisinin değiştirilmesi talepleri olmaktadır. Bu sebeple de, kıyı bölgelerinde kamunun yararlanacağı alanlar giderek azalmaktadır. Bu çalışmada; Acısu ile Akdeniz sahili arasında kalan kara parçasının kıyı kullanımı incelemiş kıyı kenar çizgisinin özel konumu ortaya konmuştur.

Anahtar Kelimeler: Kıyı, Kıyı kenar çizgisi, Acısu Deresi, Belek

Abstract: Antalya coast, which is approximately $640 \mathrm{~km}$ long, has been one of the most important tourism areas in Turkey. The coastal area has been destroyed rapidly because of the construction. Belek coasts constitute a good habitat for flora and fauna types due to its micro climatic features that also give rise to a very attractive holiday and rest place. In addition Belek coast, were shaped with coastal dunes of about $29 \mathrm{~km}$ littoral area. It's quite rich in natural life way and as a little living environment. With increase in tourism activity makes Belek coast to become very striking. According to coast law between shoreline and coastal edge is what's called a coast. Recently, to benefit much from coast area human origin has been intervened. In this type of area, redefining form another different shoreline. The sea side of the shoreline primarily use by public not the private sector. For this reason, the areas in which the people can benefit from coastal regions are gradually diminishing. In this study; the area between Acisu and Akdeniz coast were studied and described as special coastline site).

Key Words: Coast, Shore edge line, Aclsu Stream, Belek 


\section{GíRIŞ}

Kıyı çizgisi ile kıyı kenar çizgisinin zaman içinde değişebilen özelliği nedeniyle kıyı ile ilgilenen bilim adamları, mühendisler ve yerel yöneticiler için büyük öneme sahiptir. Kıyı alanlarının yönetimi ve mühendislik tasarımları için kıyı çizgisinin geçmişteki ve gelecekteki konumunun ne olacağının tahminine yönelik bilgiye ihtiyaç vardır. Örneğin, kıyı koruma alanlarının tasarımı için, deniz seviyesindeki artış bilgileri, kıyı güvenliği açısından tehlikeli bölgeler, kıyı gelişsimi düzenleyen politikalar üretilmesi, yasal mülkiyet sınırlarının tanımı ile birlikte kıyı araştırma ve izleme bilgileri gereklidir.

Akdeniz kıyıları, tarih boyunca farklı uygarlıkların yerleşim yeri olmuştur. Bunun temel nedeni kıyıların kara ile su arasında bir geçiş noktası olması ve insanların suya olan vazgeçilmez ihtiyacıdır. Dört farklı denize kıyısı bulunan ülkemiz, kıyılarının uzunluğu, doğal, ekolojik ve turistik zenginliği bakımından Dünya'nın sayılı ülkelerinden birisidir. Kıyı kavramı yalnız deniz ile karanın birleşme noktasını anlatan bir kavram değildir. Kıуı kavramına her türlü su kütlesini çevreleyen kara parçası girmektedir. Bu bakımdan doğal ve suni göller ile akarsular da önemlidir.
Belek Bölgesi, Akdeniz sahillerinde, Antalya ilinin 30 kilometre doğusundadır (Şekil 1). Çalışma alanı olarak seçilen Belek Turizm kıyı bandında büyük ölçekli turizm tesisleri yoğunlaşmıştır. Belek kıyısı, kumulların biçimlendirdiği 29 km kıyısal alana sahiptir. Endemik türlerdeki flora ve faunanın yaşama ortamıdır. Bölgede tesis türleri Kültür ve Turizm Bakanlığı tarafından 13 gruba ayrılmıştır (İnam, 2009). Bu kadar farklı türde tesisin bir arada bulunduğu bölge, sunulan mekan, servis çeşitliliği ve mimari zenginlik açısından da oldukça ilginçtir. Ancak ekolojik açıdan hassas olan bölgede, 47 tesisin 11'inde golf tesisi bulunmaktadır. Bölgede konaklama yapılarının inşasına 1990'l1 yıllarda başlanmış, tesisler o zamanki turizm anlayışı ve turist talepleri doğrultusunda şekillendirilmiştir. İlk yapılan oteller mimari ihtiyaç programı, kapasite artışı ve farklı turistik taleplerden dolayı sürekli olarak değişime uğramıştır. Özellikle son yıllarda Akdeniz kıyılarının iç ve dış turizm talebine bağlı olarak yoğun bir nüfus baskısı altına girmesi, ikincil konut ve tatil siteleri yapımı, koruma alanlarında günü birlik turizm adına yapılan uygulamalar kıyılarımızın doğal güzelliğinin yok olmasına neden olmaktadır (Şekil 2 a-b). 


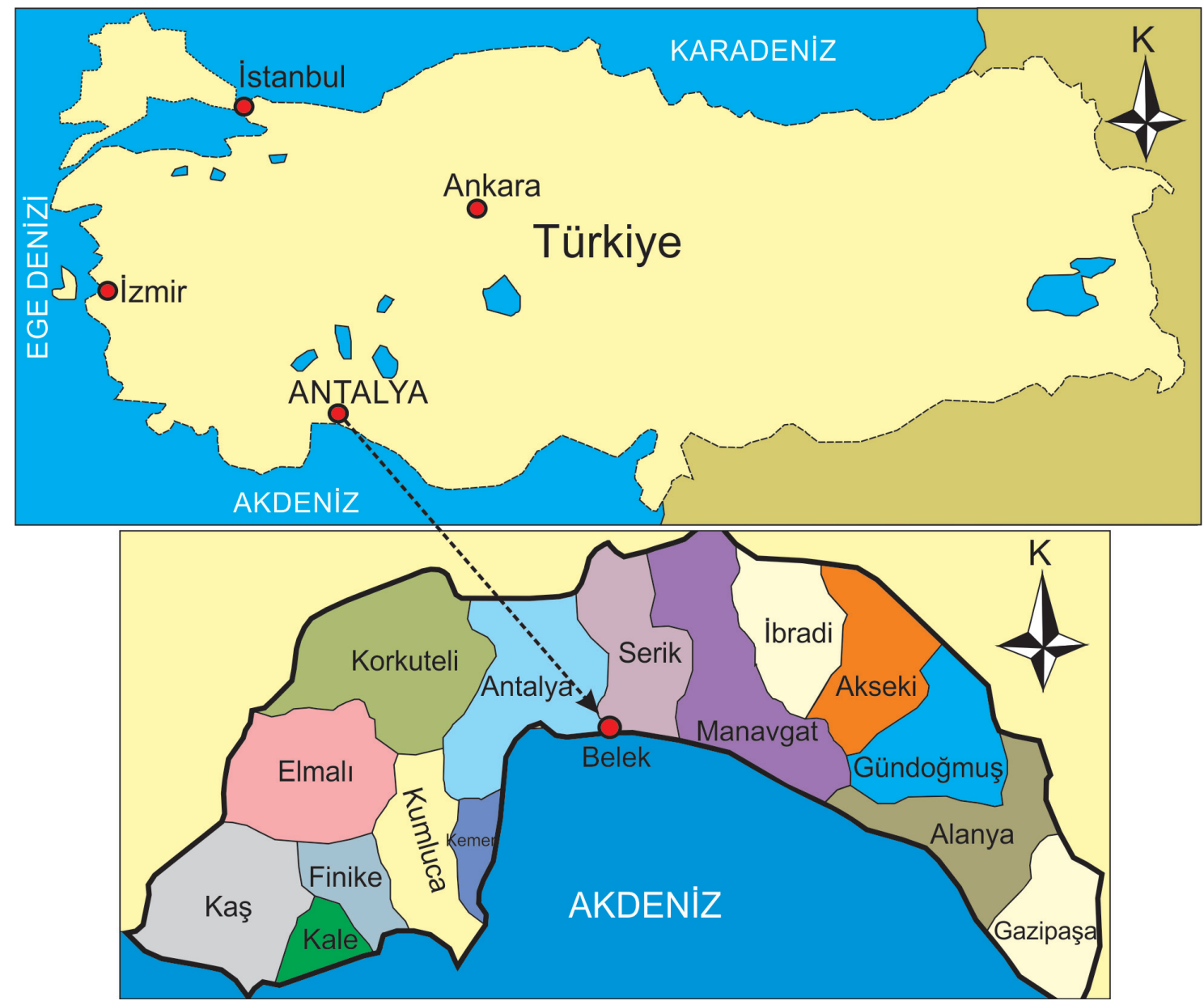

Şekil 1. Çalışma alanı yer bulduru haritası

Figure 1. Location map of the study area

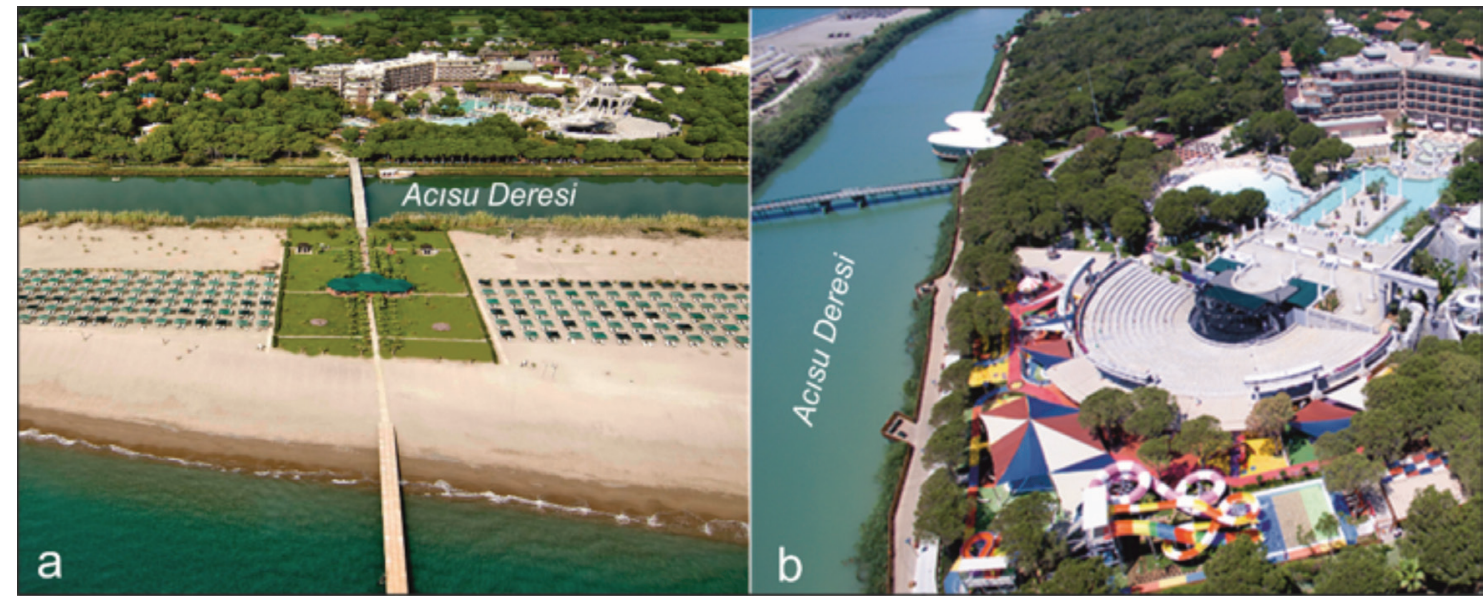

Şekil 2. Belek turizm tesisleri (a) ve Acısu Deresinin görünümü (b) (http://www.etstur.com/ Xanadu Resort Hotel, 2016)

Figure 2. (A-B) Belek tourism facilities and view of Ac1su Stream (http://www.etstur.com/ Xanadu Resort Hotel, 2016) 
Belek kıyısının önemi jeolojik, jeomorfolojik, hidrolojik, flora-fauna ve oşinoğrafik özelliklerinden dolayıdır. Belek bölgesi irili ufaklı altı akarsuya sahiptir. $\mathrm{Bu}$ akarsular batıdan doğuya doğusuna doğru olmak üzere sırasıyla; Acısu Deresi, Köprüçay Irmağı, Sarısu, Karaöz, Şarlavuk ve İncirli dereleridir. Bölgede kumulların uzun yıllar içinde oluşturduğu arazi formu, bitkilerle stabilize olmuştur. Endemik Serik armudu (Pyrus serikensis), Endemik balık türü Aphanius anatoliae, Caretta caretta ve Chelonia mydas deniz kaplumbağası türleri bölgenin zenginlikleri arasında yer almaktadır. Belek bölgesi sınırları içerisinde Acısu Deresi ağzından Sarısu Deresine kadar uzanan yaklaşık 13,3 km' lik alan deniz kaplumbağaları üreme alanıdır (Şekil 3 a-b). Ayrıca, Belek denizel alanında yüzey akıntıları Levant Denizinin genel akıntı sistemine uyum göstermektedir. Rüzgar ve dalga etkenli beklenen bu akıntının hızı, en yüksek kıyı boyu yüzey akıntıları yaklaşık olarak $14 \mathrm{~cm} / \mathrm{s}$ değerinde olup, taban sularında bu değer yaklaşık $5 \mathrm{~cm} / \mathrm{s}$ 'ye azalmaktadır. Akıntı sisteminin yapısı genel olarak değişmemekle birlikte mevsimlere ve meteorolojik şartlara bağlı olarak sürati değişmektedir (Eryılmaz ve Yücesoy Eryılmaz,
2002). Kıyılarda akıntı yönü ise genellikle doğu yönlüdür. Yıl içerisinde akıntı yön ve şiddetlerinde önemli ölçüde değişim görülmektedir (Tziperman ve Malenotti Rizzoli, 1991). Belek kıyı bandında, plajlar açısından etkili olan rüzgar yönü GüneyBatı ve Bat1-Güney-Batı ve hızı 5-20 m/s'dir. Çalışma sahası denizel alanında, konum olarak en çok Bat1-Kuzey-Bat1 ve Doğu-Güney-Doğu yönleri aralığından gelecek dalgalar etkili olan dalgalardır. Bölgede, etken dalga ilerlemesi yön aralığ1 Bat1-Güney-Bat1 ve Güney-Doğu yönleri aralığındadır. Genel olarak, güney batılı yönlerden yılda 1 saat aşılma olasılığı ile 3.5 m'den fazla derin deniz dalga yüksekliğine sahip dalgalar yaklaşırken, güney doğulu yönlerden yılda 1 saat aşılma olasılığ ile 3 m'den fazla derin deniz dalga yüksekliğine sahip dalgalar yaklaşmaktadırlar (Numanoğlu Genç, 2016). Yıllık ortalama gelgit seviye farkı ise $50 \mathrm{~cm}$ 'yi geçmemektedir (Alpar vd. 2000). Numanoğlu Genç (2016)'nın Alara Çayının Antalya Körfezine bağlandığı kıyı bölgesinde yaptığı modelleme sonucuna göre Kıyı boyu sediman taşınımı Batı-Kuzey-Batı ve DoğuGüney-Doğu doğrultusunda gerçekleşmektedir. Tüm bu faktörler plajların dokusunu belirlemede önemli rol oynamaktadır (Koç vd. 2015).

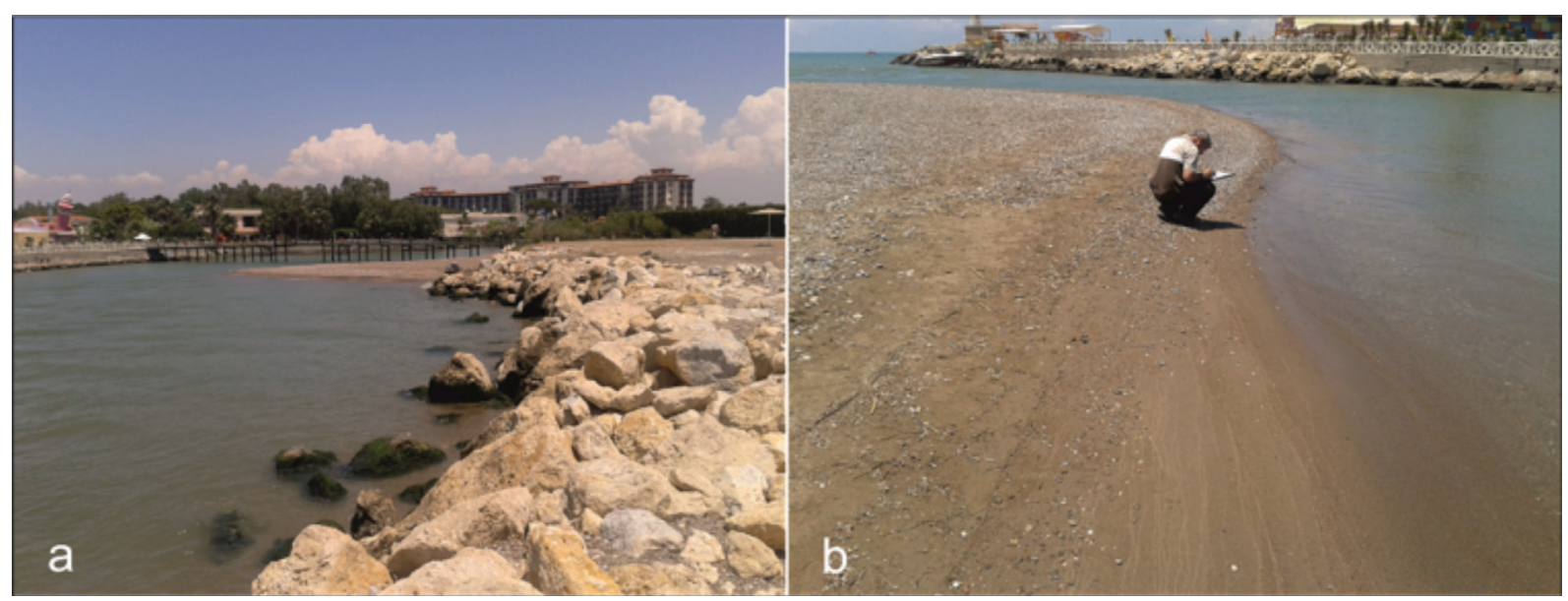

Şekil 3. Acısu Dere ağzının güneyden görünüşü (a), Kuzeyden görünüşü (b)

Figure 3. Acisu stream's view from the south (a), from the north (b) 
Turizm tesislerinin deniz kıyssndan geriye çekilmesi, hareketli kumulların bir sonucudur. Çünkü özellikle kış sezonunda zaman zaman esen lodos, kıyıdaki kumların taşınmasına neden olmaktadır. Fakat çok katlı ve geniş bir alanı kaplayan turizm tesisleri kıyılardaki doğal süreci engellemektedir (Şekil 4 a-b). Ayrıca sadece deniz manzarası yaratmak amacıyla yapılan arazi düzleştirme çalışmaları, daha sonraki zamanlarda bakım ve düzenleme yönünden çok daha büyük zarara ve zaman kaybına neden olmaktadır (Şekil 5 a-b). Bu amaçla doğal morfolojiyi ve kumul tepelerini koruyan tesisler doğal bitki ve canlılarında korunmasını sağlamış olacaktır (Sayan, 1999).

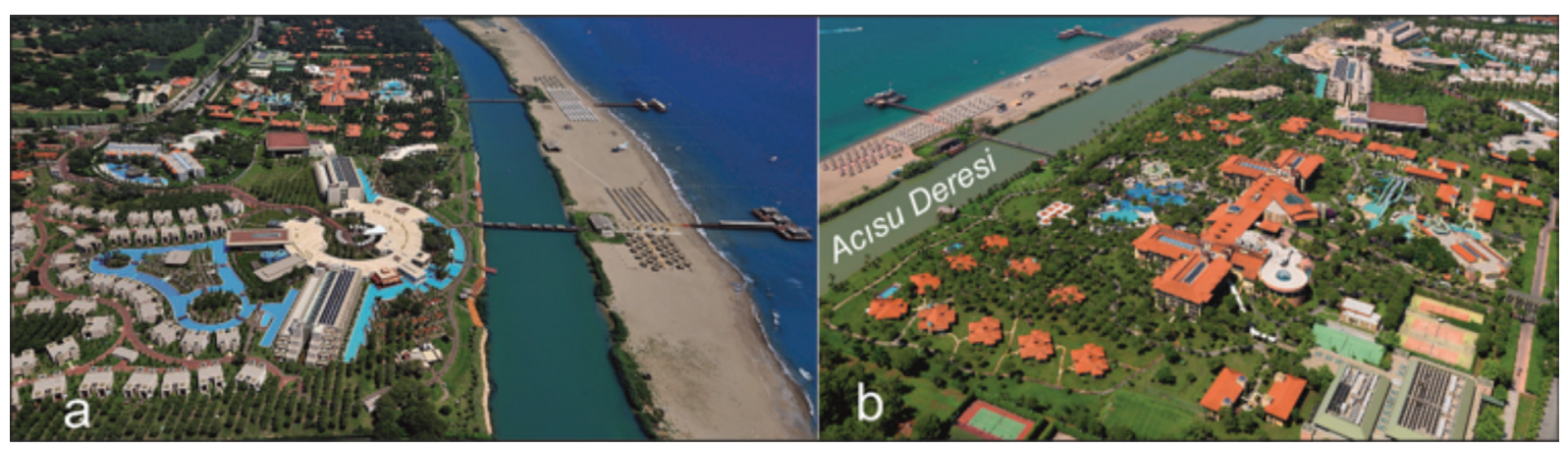

Şekil 4. Acısu Deresi yanındaki turizm tesislerinin görünümü (a-b) (http://www.etstur.com/Gloria- Serenity-Resort, 2016)

Figure 4. The view of the tourist facilities near Ac1su (a-b) (http://www.etstur.com/Gloria-Serenity-Resort, 2016)

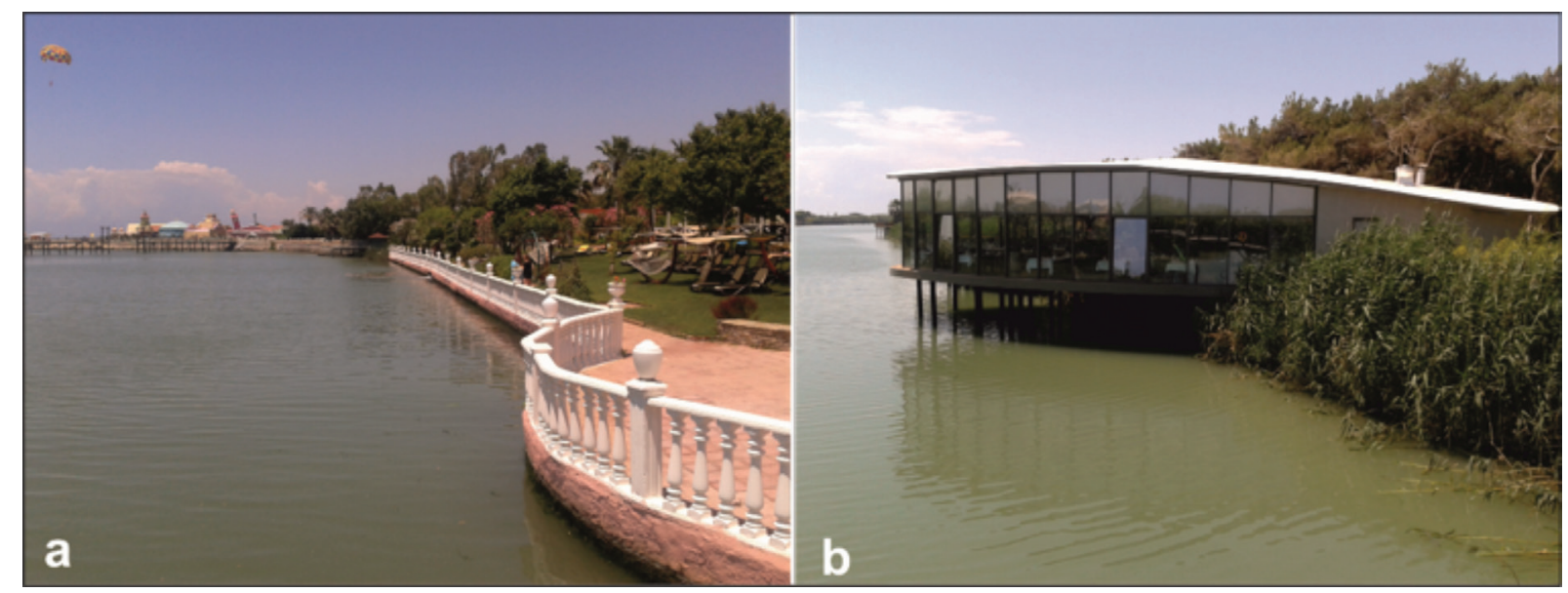

Şekil 5. Acısu Deresi sağ sahilinde doğal ortama yapılan sınırlamalar (a), sol sahilinde yapılan sınırlamalar Figure 5. Restrictions on the natural habitat on the right bank of the Acisu Stream (a), restrictions on the left bank (b) 


\section{YÖNTEM}

Kıy1 kenar çizgisinin önemini vurgulamak amacıyla hazırlanan bu çalışmada; Acısu Deresi ile Akdeniz sahili arasında kalan kara parçasının kıyı kullanımı incelemiş Kıyı Kenar Çizgisinin özel konumu ortaya konmuştur. Özellikle, Acısu Dere yatağının sahilin şekillenmesinde önemli rol oynadığ 1 görülmektedir. $\mathrm{Bu}$ nedenle derenin kıyı bölgesi ve denize döküldügü kesimler dikkate alınmıştır. Jeolojik, jeomorfolojik ve jeoteknik incelemeler gerçekleştirilmiştir. Yapılan incelemelerde, litolojik gözlemlerin yanı sıra, sahanın topoğrafik, jeomorfolojik ve toprak oluşumu ve bitki gelişimi gibi özellikleri de dikkate alınmıştır.

Büro çalışmalarında; birçok parametre dikkate alınarak (litolojik incelemeler, topoğrafya haritaları, Google Earth görüntülerinin değerlendirilmesi gibi) kıyı kenar çizgisinin konumu araştırılmıştır.

Arazi çalışmalarında ise aşağıda verilen parametreler ve 3621 sayılı Kiy1 Kanununda belirtilen hususlar dikkate alınarak, 28.06.2010 tarihli KKÇ iptal edilerek 31.08.2008 tarihinde onaylanan kıyı kenar çizgisinin geçerliliğinin uygun olup olmadığ incelenmiştir. Bu amaçla, jeolojik, jeomorfolojik ve jeoteknik olarak kritik noktalarda traktör kepçe ile gözlem çukurları açılmıştır. Açılan gözlem çukurlarından örnekler alınarak zemin mekaniği laboratuvarında zemin sınıflaması deneyleri yapılmıştır. Yapılan deney sonuçları Birleştirilmiş Zemin Sınıflaması yöntemine göre değerlendirilmiştir. Böylece, kıyı kenar çizgisi tespitindeki jeolojik, jeomorfolojik, topoğrafik, zeminlere ait bulgular, önceki kıyı kenar çizgisi tespit raporları ve kıyı kenar kanun ve yönetmelikleri birlikte ele alınarak sonuca gidilmiş ve önerilerde bulunulmuştur.

\section{BÖLGENIN JEOLOJISII VE KIYI YAPISI}

İnceleme alanı, Antalya Neojen havzası içerisinde yer almaktadır. Antalya Neojen Havzası, birbirinden bağımsız olarak gelişen Beydağları Miyosen havzası, Antalya Miyosen havzası ve tümüyle diğerlerinden bağımsız olarak gelişen Antalya Üst Miyosen-Pliosen havzası ile temsil edilir (Akay vd. 1985 a,b). Belek ve civarı, Antalya Miyosen ve Antalya Üst Miyosen-Pliosen havzalarında yer almaktadır. Antalya Miyosen havzası içerisinde; kireçtaş1-killi kireçtaşı-breşik kireçtası ardalanmasından oluşan Geceleme Formasyonu, şeyl-kumtaş1-çakıltaşından oluşan Karpuzçay Formasyonu yer almaktadır. Prodelta ortaminı yansitan Geceleme Formasyonu, alan içerisinde en dar yayılıma sahip formasyondur. Karpuzçay, en geniş alan kaplayan formasyondur. Delta özelliği taşıyan Karpuzçay Formasyonu, ince-orta-kalın tabakalı gri, kirli sarı, yeşil, bej, krem renklerde kumtaşı, kiltaşı ve silt taşlarından oluşmaktadır (Glover ve Robertson, 1998). Antalya Üst Miyosen-Pliosen havzası içerisinde ise, Messiniyen yaşında çakıltaşı, kumtaşından oluşan Eskiköy Formasyonu, Alt-Üst Pliosen yaşında killi kireçtaş1-kumtaş1, şeylden oluşan Yenimahalle Formasyonu yer almaktadır (Akay vd. 1985 a,b). Eskiköy Formasyonu, Karpuzçay Formasyonu üzerine uyumsuzlukla gelmektedir. Formasyonun tortulanma özellikleri kıyı yakınındaki alüvyal yelpaze ortamını yansıtmaktadır. Karpuzçay'ın batısındaki sirtlar, Yenimahalle Formasyonuna ait kayaçlardan oluşmaktadır. Yenimahalle Formasyonunu oluşturan unsurlar dalga tabanı altında bir körfezde çökelmiştir. Pleistosen yaşlı Belkıs çakıltaşı Antalya Miyosen havzasının güneyinde aşağı yukarı deniz kenarı boyunca bir uçtan diğer uca kadar uzanmaktadır. Bunların dağılımları incelendiğinde, bugünkü akarsuların eski birikintileri olduğu kolayca anlaşılır. Birim, yaklaşık 0-20 m kalınlıktadır (Şekil 6). 


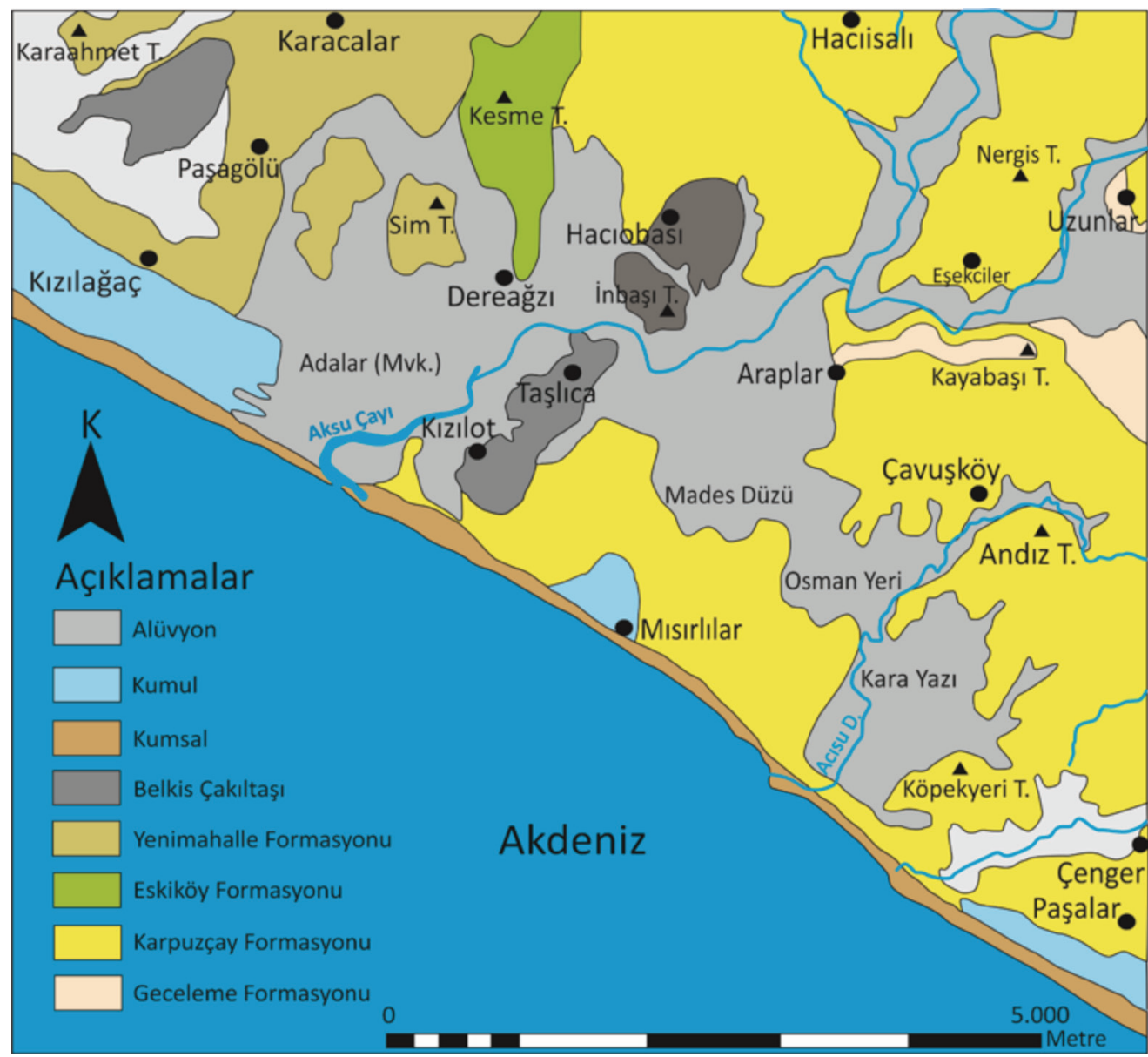

Şekil 6. Belek ve civarının jeoloji haritası (Akay vd. 1985'den alınmıştır)

Figure 6. Geological map of Belek and its surroundings (taken from Akay et al., 1985)

Çalışma alanı ve civarındaki jeolojik birimler olarak, Karpuzçay Formasyonu ve alüvyonal birimler bulunmaktadır. Bunlardan Karpuzçay formasyonu Miyosen, Alüvyon ise Kuvaterner yaşlıdır. Batı Toroslar kıvrım kuşağının güney kesiminde kalan bu alanda denizin çekilmesi Geç Pliyosen'de gerçekleşmiştir. Bu nedenle yöredeki en yaşlı morfolojik birimler Geç PliyosenErken Pleyistosen yaşlı aşınım yüzeyleridir. Yükseltileri 100-120 m civarında olan bu yüzey parçaları Belek yerleşim alanının kuzeyinde yer almaktadır. $\mathrm{Bu}$ yüzeyler $\% 2-5$ eğimle denize doğru uzanmaktadır. Yörede görülen Pleyistosen yaşıı Belkıs konglomeralarıdır. $\mathrm{Bu}$ aşınım yüzeyleri genelde eğimi \%20'yi geçen yamaçlarla diğer birimlerden belirgin şekilde ayrılmaktadır.
Kuzeydeki aşınım yüzeylerine yaslanan kesimlerde, Pleyistosen'de oluşmuş ova ve vadi tabanları tektonik deniz seviyesi değişmelerine bağlı olarak 4 basamak halinde seki düzlüklerine dönüşmüştür. Bu basamaklar 70-80, 40-50, 20-30 ve $10 \mathrm{~m}$ yüksekliğinde bulunmaktadır. Litoloji farklılı̆̆ına bağlı olarak seki yüzeylerinin eğimleri \%2-10 arasında değişmektedir. Bölgedeki yüksek ve engebeli kesimleri oluşturan aşınım yüzeyleriyle aşağı kesimlerde yer alan sekiler, akarsularla yer yer derin bir şekilde yarılmıştır. Akarsular, yukarı kesimlerde genellikle tabansız dik yamaçlı vadilerde, aşağ 1 kesimlerde ise delta düzlüklerindeki nispeten geniş yataklarında akmaktadır. Karpuzçay ve Acısu Deresi'nin taşıdığ1 alüvyonlar yörede Kızılot adı verilen 
delta ovasını oluşturmuştur. Karpuzçay'ın ağız kesimindeki lagün ile deniz arasındaki bağlant, akarsuyun taşıdığı su miktarına göre açılıp kapanabilmektedir. Ayrıca, Acısu Deresi'nin güneyinde ve doğu-kuzeydoğusunda yer alan tuzlu-alkali ve taban suyu yüksek ve zaman zaman da geçici yüzlek göl haline dönüşen alanlarla ve ayrıca daha doğudaki Kocagöl sulak alanı bulunmaktadır (Kaman vd. 2011).

Küçük bir havzaya sahip olan Acısu, Karpuzçay'dan daha farklı bir gelişim izlemiştir. Acısu Deresi'nin ağzındaki kıyı kordonunun gerisinde bir lagün gelişmiştir (Şekil $7 \mathrm{a}-\mathrm{b}$ ). Hava ve uydu fotoğraflarından izlenen eski yatak izleri, terk edilmiş bir delta lobunun ve doğal set depolarının bulunması, akarsuyun sik sik yatak değiştirdiğini göstermektedir (Çiçek vd. 2008). Bu birimlerin yoğun tarımsal faaliyetlere rağmen hava ve uydu fotoğraflarında belirgin şekilde görülmeleri, günümüzden 2000 yıl önce Acısu Deresi'nin ağzında bir bataklığın olması, belirtilen değişimlerin Milat yıllarından sonra meydana geldiğini ortaya koymaktadır (Çiçek vd. 2008). Bu bölgede, kıyı şeridini çevresel koşullara bağlı olarak zaman zaman daralıp genişleyen bir kumsal oluşturmaktadır (Şekil 8 a-b). Kumsalı oluşturan ince kumlar, rüzgarlarla iç kesimlere doğru taşınmış ve yer yer yükseltisi 5-10 m’ye ulaşan kumulları oluşturmuştur. Bu kumullar, 10 $\mathrm{m}$ sekisinin yamaçlarına yaslanmış durumdadır (Şekil $9 a-b)$.

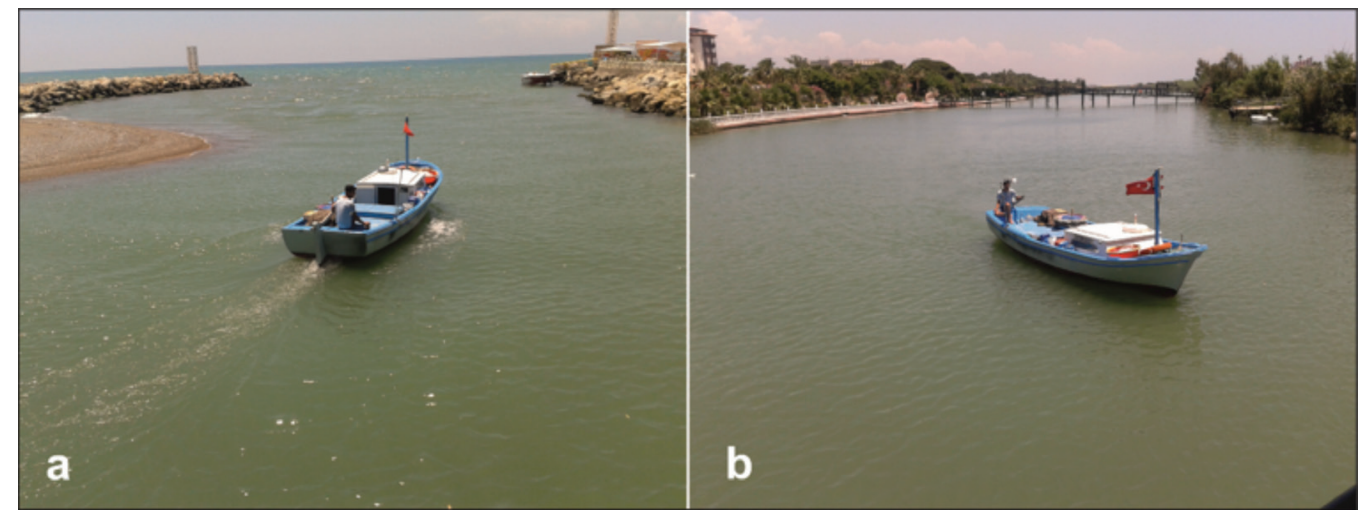

Şekil 7. Acısu Deresinin Akdeniz’le birleştiği kesimin kuzeyden görünümü (a), güneyden görünümü (b)

Figure 7. View of Acisu Stream merged with Mediterranean, from the north (a), from the south (b)

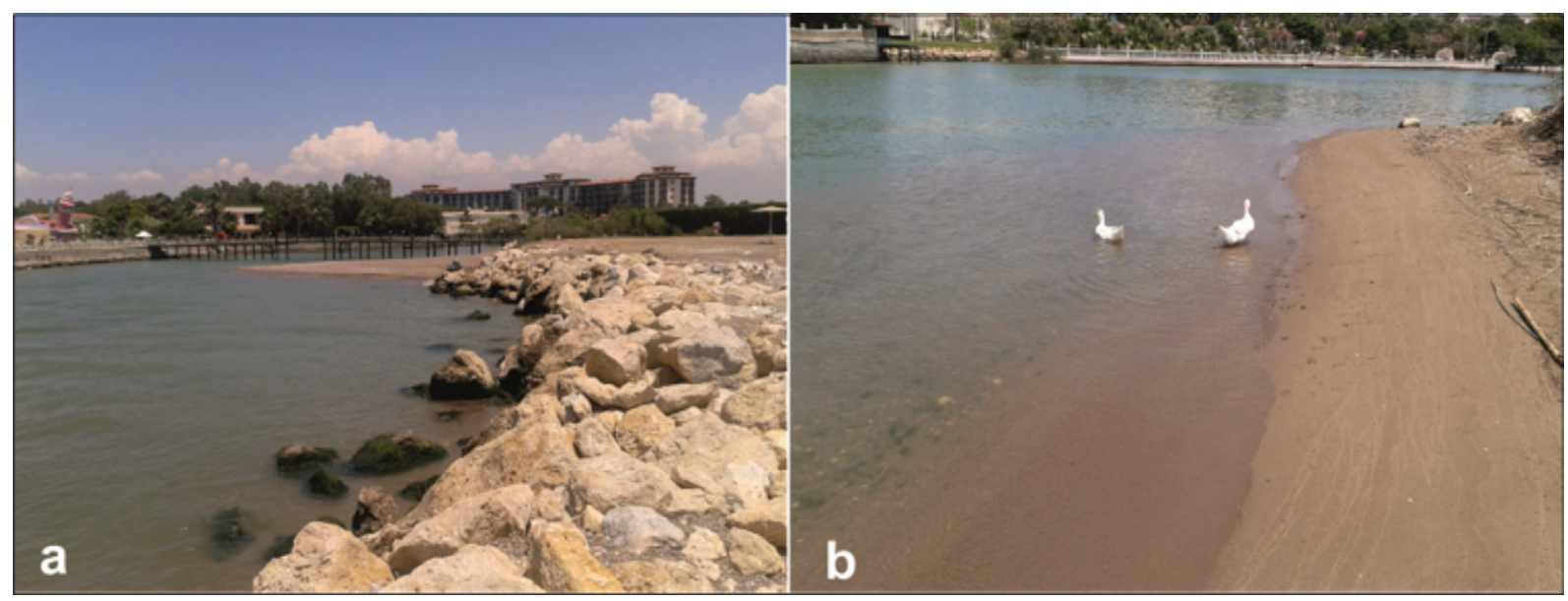

Şekil 8. (a-b) Acısu Deresinin Akdeniz'le birleştiği yerde zamanla artan-azalan kumullar

Figure 8.(a-b) Increased-dwindling dunes over time where Acısu Stream's merges with the Mediterranean 


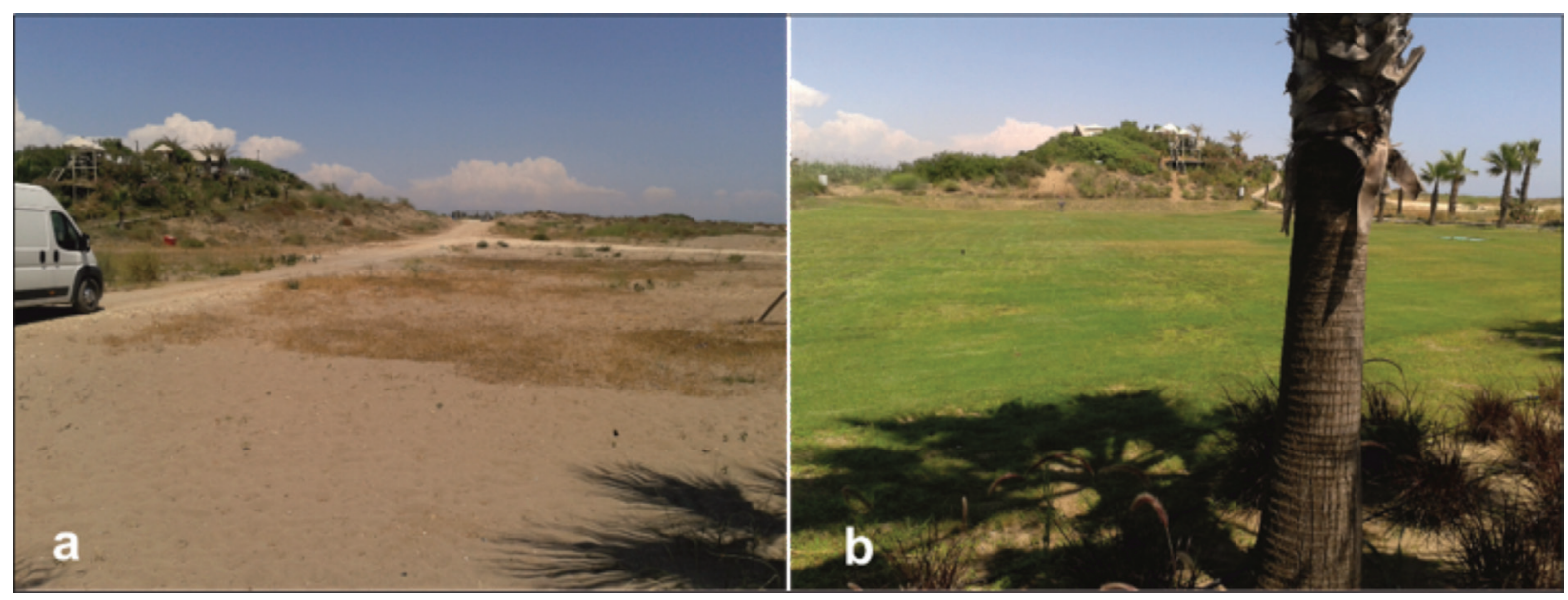

Şekil 9. (a-b) Acısu ile Akdeniz arasında oluşan kumul tepeleri

Figure 9. (a-b) Dunes formed between Aclsu and Mediterranean

\section{BULGULAR}

Bugün kıyılar sadece kara ile su arasındaki bir sınır çizgisi biçiminde değil, denizden karaya doğru şeritler şeklinde uzanan, kıyının kullanım ve korunmasını sağlayan ve buranın doğal yapısına uygun olarak uzunlamasina ve derinlemesine olmak üzere iki boyutlu bir takım bölgeleri kapsayan bir alan olarak kabul edilmektedir. Kıyının bir alan olarak algılanması bu alanın alt ve üst sınırlarının belirlenmesini gerektirir (Çelik, 2015). 3621 Sayılı Kıyı Kanunu, kıyının bir alan olduğunu belirterek alt ve üst sınırlarını belirlemek üzere kıyı çizgisi ve kıyı kenar çizgisi terimlerini kullanmış ve bunları tanımlamıştır. 3621 sayılı Yasanın 4. maddesinde belirlendiği biçimde, Kıyı kenar çizgisi, kıyı çizgisinden sonraki kara yönünde, su hareketlerinin oluşturduğu kumluk, çakıllık, kayalık, sazlık, bataklık ve benzeri alanların doğal sınırı olarak tanımlanmıştır (TC Resmi Gazete, 1990). Kıyı çizgisi ise, suyun karaya değdiği noktalardan oluşan, bir yönü su, diğer yönü kara olan, tek boyutlu bir çizgidir. Kıyı ise, kıyı çizgisi ile kıyı kenar çizgisi arasında kalan alanı belirler (Şekil 10). Bu duruma göre; kıyı kenar çizgisi, kıyı denilen alanı doğrudan belirleyen bir kavram olarak karşımıza çıkar. Günümüzde sosyal-ekonomik ve teknolojik gelişim sonucu çeşitli kullanım isteklerinin doğması ve artması kıt kaynak konumunda bulunan kıyının hukuksal yapısı ve kullanımı yönünden ciddi tartışmalara neden olmuştur. Kıyılarda kamu kullanımına açık yeterli alanlar bırakılması, kıyı ekosisteminin korunması ve kıyı ve sahil şeridinde yapılacak planlamanın ilk adımı, kıyı kenar çizgisinin doğal ve bilimsel verilere uygun bir biçimde tespit edilmesidir (Özyurt, 2012). 


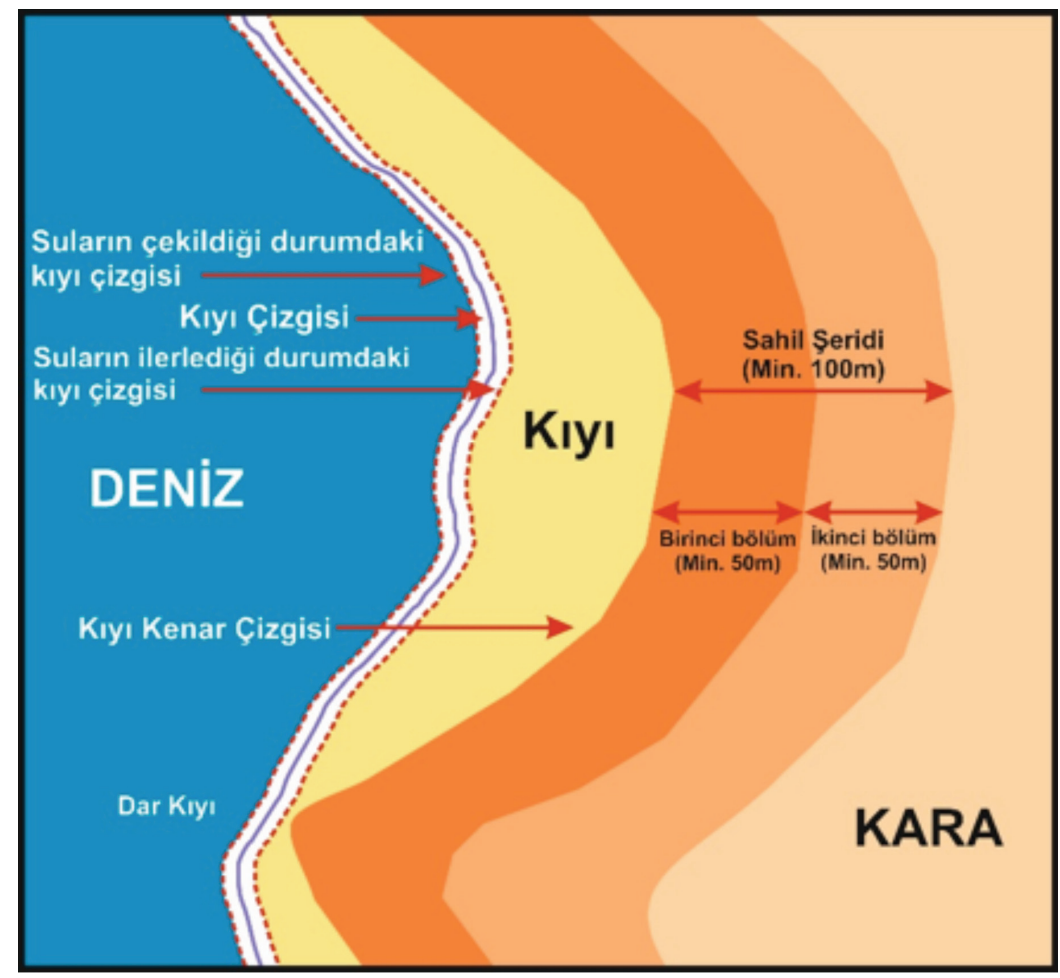

Şekil 10. Kıyının Bölümleri (Turoğlu, 2009'dan yeniden çizilerek)

Figure 10. Section of the Coast (redrawn from Turoğlu, 2009)

Belek ve civarında bulunan Acısu Deresi, Köprüçay ırmağı, Sarısu, Karaöz, Şarlavuk ve İncirli akarsuları bölgenin özel konumuna ayrı bir katkı sağlamaktadırlar ve kıyı kanunda da özel öneme sahiptirler. Şöyle ki, akarsuların yıl içerisinde düzenli akış gösterdikleri dar ve uzun çukura akarsu yatağ 1 adı verilmektedir. Akarsular olağanüstü taşkın durumları hariç genelde bu yatak içerisinde kalmaktadırlar. Düzenli akışı sırasında suyun karaya değdiği noktaları birleştiren çizgiye Akarsu Kıyı Kenar Çizgisi adı verilmektedir. Meteorolojik olaylara göre akarsu seviyesi yıl içerisinde veya zamanla değişmekte olduğundan bu çizginin belirlenmesinde, akarsu yatağındaki jeomorfolojik yapılar veri olarak kullanılmalıdır (Ferudun 2009). Kıyı Kanunu'nun uygulanmasına ilişkin yönetmeliğinin 4. maddesi gereğince akarsular içinde kıyı kenar çizgisinin tespiti zorunludur.
Acısu Deresi ile Akdeniz sahili arasında kalan kara parçasının kıyı kullanımı incelemiş Kıyı Kenar Çizgisinin ve Akarsu Kıyı Kenar Çizgisinin özel konumu ortaya konmuştur. Özellikle, Acısu Dere yatağının sahilin şekillenmesinde önemli rol oynadığ1 görülmektedir. Bu nedenle derenin kıyı bölgesi ve denize döküldüğü kesimler dikkate alınmıştır. Kıyı Kenar Çizgisinin tespitindeki farklılıklar kamu kurum ve kuruluşlarının kıyıya komşu olan arazi sahipleri ve turizm sektörü işletmecilerinin karşı karşıya gelmesine neden olan en önemli sorunlardan birisidir. Problemin çözümüne yönelik gerçekleştirilen çalışmalarda da farklı yaklaşımlar dikkat çekicidir.

$\mathrm{Bu}$ çalışma kapsamında büro ve arazi çalışmaları gerçekleştirilmiştir. Gerçekleştirilen büro çalışmalarında; birçok parametre dikkate alınarak (litolojik incelemeler, topoğrafya 
haritaları, Google Earth görüntülerinin değerlendirilmesi gibi) kıyı kenar çizgisinin konumu araştırılmıştır. Acısu Deresi ve etrafında bulunan sahilin düz-düze yakın eğimde olduğu gözlemlenmiştir. Arazi çalışmalarında aşağıdaki verilen parametreler ve 3621 sayılı Kiy1 Kanununda belirtilen hususlar dikkate alınarak kıyı kenar çizgisinin geçerliliğinin uygun olup olmadığı incelenmiştir. Çalışma alanında yapılan gözlemler ve jeolojik, jeomorfolojik ve jeoteknik açıdan kritik olan noktalardan Gözlem Çukurları açılarak numuneler alınmış ve litolojik kesitleri çizilmiştir (Şekil 11 a-b ve 12 a-b). Alınan zemin örnekleri laboratuvarda incelenmiştir. Zeminlerin Birleştirilmiş Zemin Sınıflamasına göre yapılan sınıflamasında SM-SC grubunda iyi derecelenmiş denizel orijinli kumlar olduğu tespit edilmiştir.

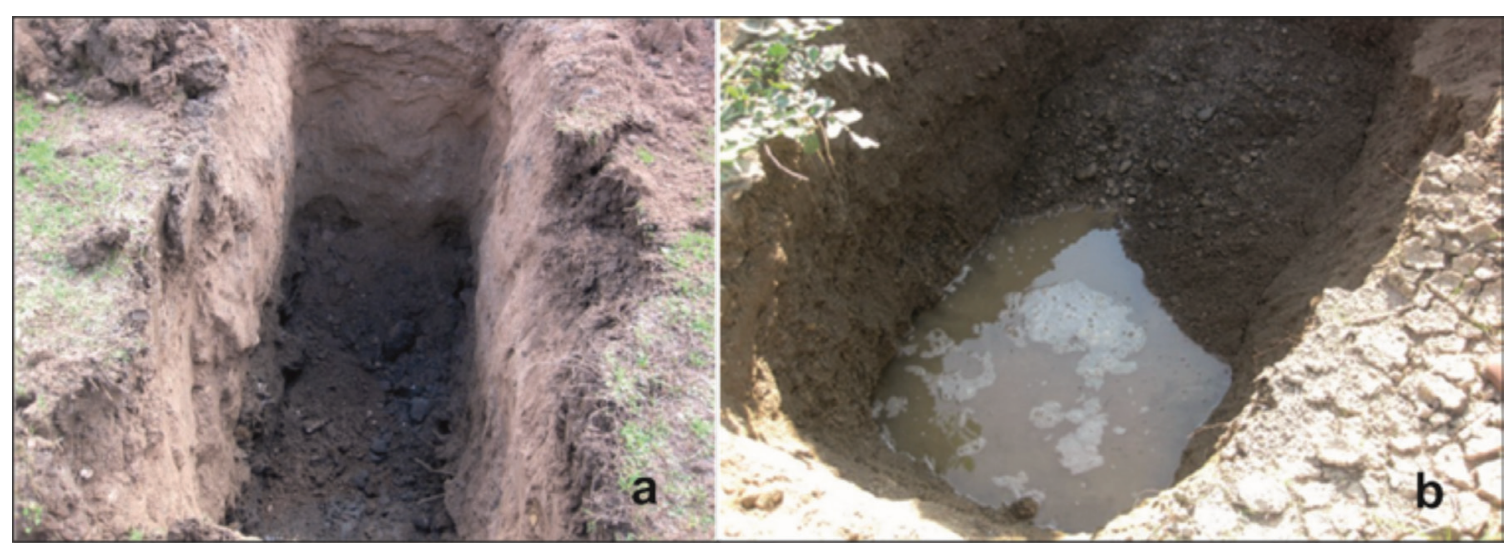

Şekil 11 (a-b). Çalışma alanında açılan gözlem çukuru (GÇ-1) ve (GÇ-3) den görünüm

Figure 11 (a-b). Views of pit excavation (GÇ-1) and (GÇ-3) studies in the study area

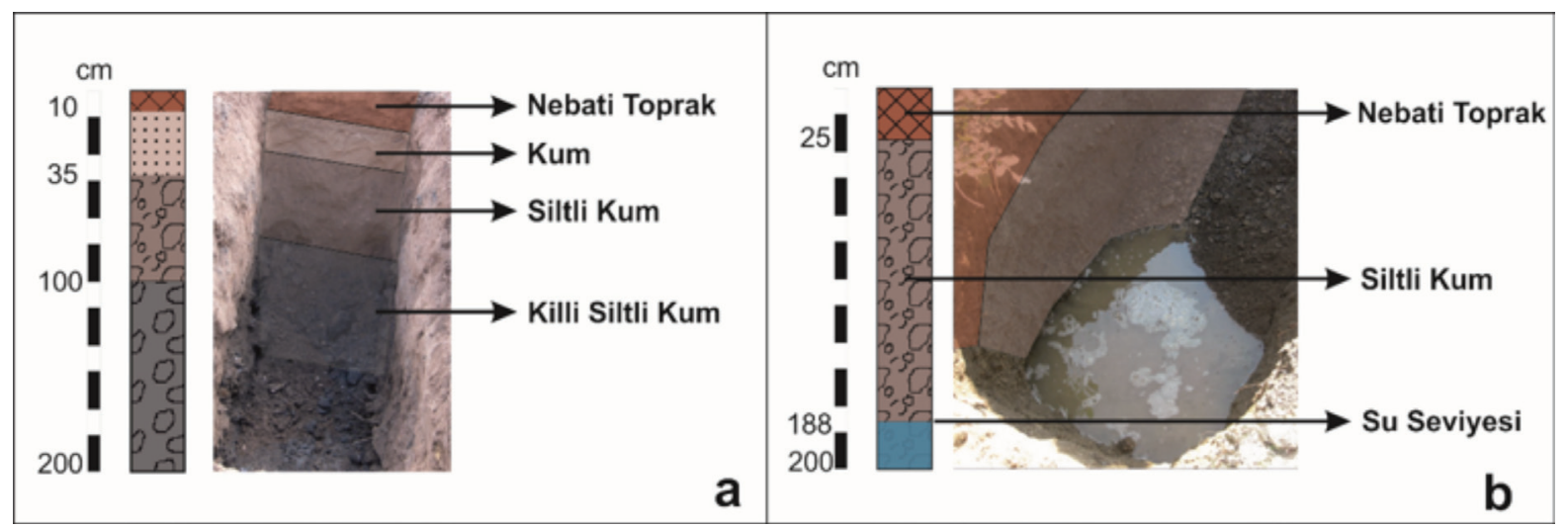

Şekil 12 (a-b). Çalışma alanında açılan gözlem çukurlarına (GÇ-1) ve (GÇ-3) ait litolojik kesitler

Figure 12 (a-b). Lithological sections of observation pits opened (GÇ-1) and (GÇ-3) in the study area 
Yapılan detaylı çalışmalar neticesinde; Acısu Deresi'nin güney sahilinin "alçak-basık kıyı" niteliğinde olduğu, deniz ve denizden sonra plaj platformu oluşturduğu tespit edilmiştir (Şekil 13 a-b). Ayrica Acısu Deresi'nin kuzey kısm1 da, "alçak-basık kıyı" niteliğinin etkisi altında kalmıştır. Ancak derenin özellikle kuzey kısmında ve güney kısmının belirli yerlerinde istinat duvarları örülerek su hareketleri engellenmiştir
(Şekil 14 a-b). Arazi çalışmalarından elde edilen parametreler ve 3621 sayılı Kiyı Kanununda belirtilen hususlar dikkate alınarak, Şekil 15'de kırmızı çizgi ile belirtilen 28.06.2010 tarihli Kıyı Kenar Çizgisi iptal edilerek Şekil 15'de yeşil renkte çizilen ve 31.08.2008 tarihinde onaylanan kıyı kenar çizgisinin geçerliliğinin uygun olup olmadığı incelenmiştir.

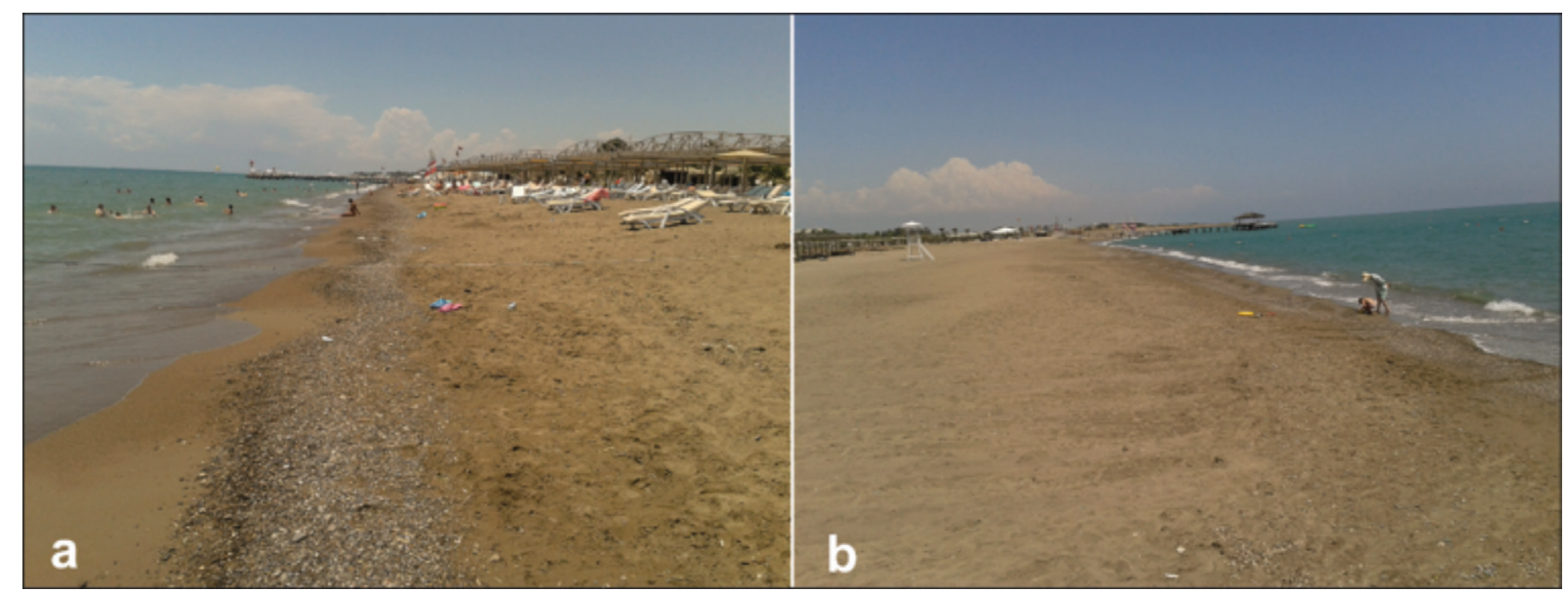

Şekil 13. Belek kıyı alanının doğudan görünüşü (a) ve batıdan görünüşü (b)

Figure 13. View from Belek coastal area from the east (a) and from the west (b)

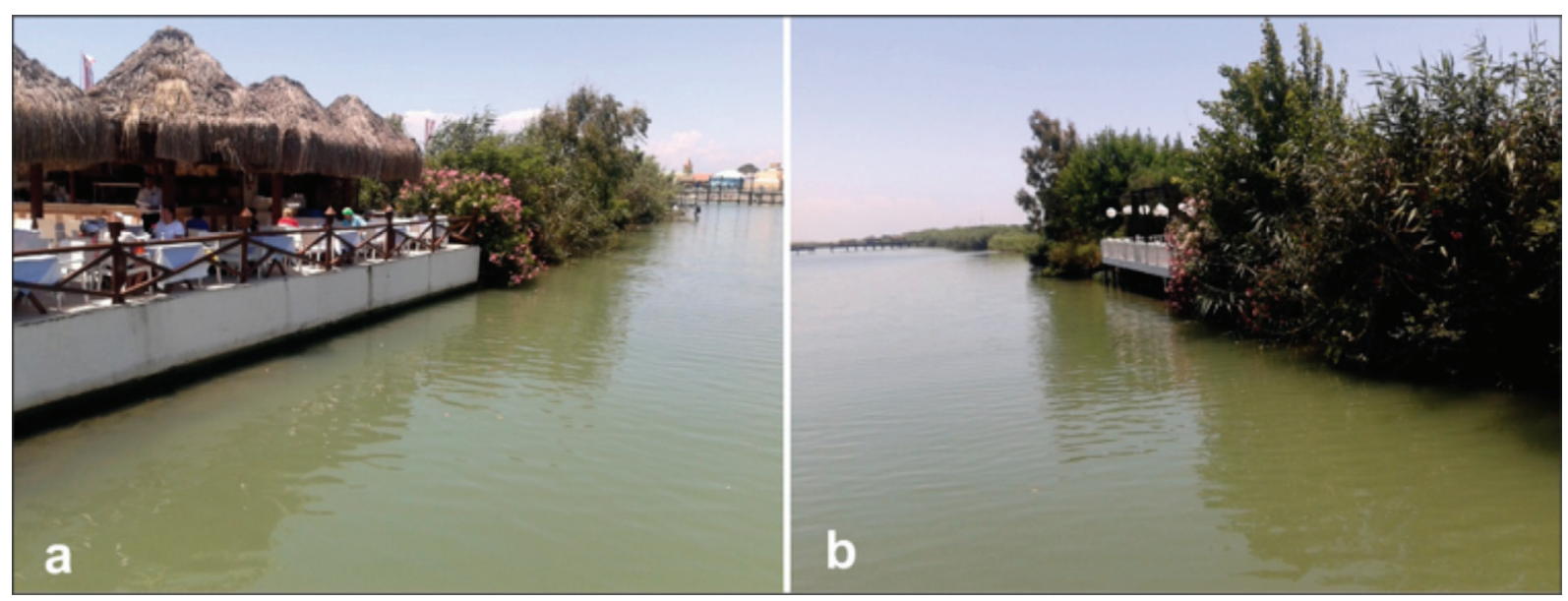

Şekil 14. Acısu Deresi'nin her iki kıyısından görünüm, sol sahil (a), sağ sahil (b)

Figure 14. View from both sides of the Acisu Stream, left bank (a), right bank (b) 
Ancak, gerek mevzuattaki eksiklikler ve sik sık yapılan değişiklikler, gerek uygulamalardaki sorunlar, gerekse denetim ve yaptırımlardaki yetersizlikler nedeniyle, bu doğal zenginliklerin gelecek nesillere, doğru ve bilinçli olarak aktarılacağını şekilde doğru ve bilinçli olarak kullanabildiğimizi söylemek olanaksızdır. sosyal ve fiziksel çevre hassasiyetlerinin dikkate alınması gerekliliği ön plana çıkmıştır.

Çalışma alanı ve civarındaki jeolojik birimler olarak, Karpuzçay Formasyonu ve alüvyonal birimler bulunmaktadır. Bunlardan Karpuzçay formasyonu Miyosen, alüvyonlar ise Kuvaterner

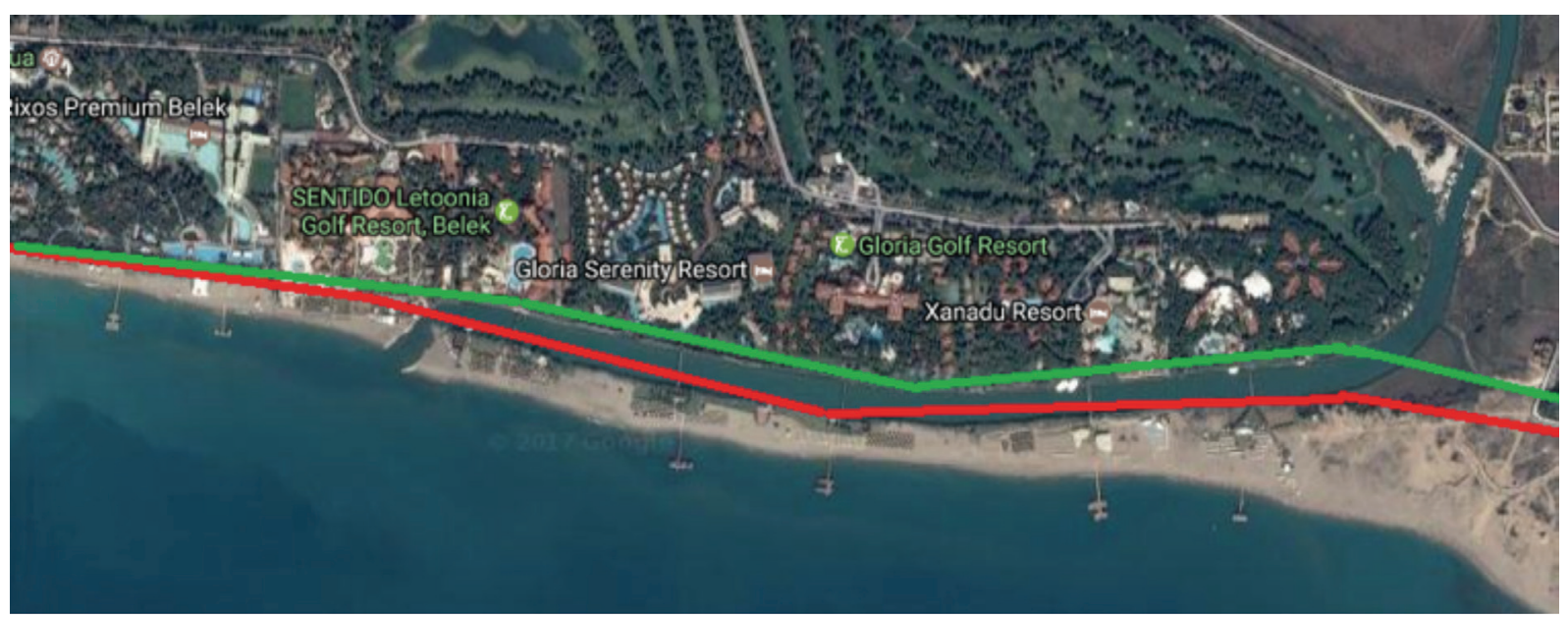

Şekil 15. Acısu Deresi’nin Kıyı Kanunu Yönetmeliğinden dolayı Kıyı Kenar Çizgisinin yeniden belirlenmesi

Figure 15. Redetermination of the Coastline Line due to the Coastal Law Regulation of the Acisu Stream

\section{TARTIŞMA VE SONUÇ}

Son 30 y1lda, Akdeniz sahilindeki kullanıc1 baskısı üç katına çıkmış, kıyıların büyük bölümü insan müdahalesi ile değişime uğramıştır. Belek kıyısının önemi jeolojik, jeomorfolojik, hidrolojik, flora ve fauna özelliklerinden dolayıdır. Gün geçtikçe gelişen turizm faaliyetleri ile Belek kıyıları daha fazla cazip kılmaktadır. Ekonomik, sosyal ve kültürel açıdan yararları olmasına rağmen turizm sektörünün iyi kontrol edilememesi durumunda, kıyı alanlarının yanlış kullanımıyla doğal alanların, tarihsel değerlerin ve sosyo-kültürel yapının zarar görmesine neden olabilmektedir. Diğer taraftan ülke ekonomisine katkıs1 düşünüldüğünde, kitle turizminden tamamen vazgeçmek mümkün değildir. Turizmin çevreye verdiği zararların en aza indirgenmesi, var olan ve yeniden planlanacak tesisler için doğal, yaşlıdır. Kıyı şeridini çevresel koşullara bağlı olarak zaman zaman daralıp genişleyen bir kumsal oluşturmaktadır. Kumsalı oluşturan ince kumlar, rüzgarlarla iç kesimlere doğru taşınmış ve yer yer yükseltisi 5-10 m' ye ulaşan kumulları oluşturmuştur. $\mathrm{Bu}$ kumullar, $10 \mathrm{~m}$ sekisinin yamaçlarına yaslanmış durumdadır. Belek bölgesi irili ufaklı altı akarsuya sahiptir. Bu akarsulardan birisi olan Ac1su Deresi'dir. Ac1su Deresi ile Akdeniz sahili arasında kalan kara parçasının kıyı kullanımı incelemiş Kıyı Kenar Çizgisinin ve Akarsu Kıyı Kenar Çizgisinin özel konumu ortaya konmuştur. Kıyı Kenar Çizgisinin tespitindeki farklılıklar kamu kurum ve kuruluşlarının kıyıya komşu olan arazi sahipleri ve turizm sektörü işletmecilerinin karşı karşıya gelmesine neden olan en önemli sorunlardan birisidir. Problemin çözümüne yönelik gerçekleştirilen çalışmalarda da farklı yaklaşımlar dikkat çekicidir. 
$\mathrm{Bu}$ çalışma kapsamında büro ve arazi incelemeleri yapılmıştır. Gerçekleştirilen büro çalışmalarında; birçok parametre dikkate alınarak (litolojik incelemeler, topoğrafya haritaları, Google Earth görüntülerinin değerlendirilmesi gibi) kıyı kenar çizgisinin konumu araştırılmıştır. Acısu Deresi ve etrafinda bulunan sahilin yataya yakın eğimde olduğu gözlemlenmiştir. Arazi çalışmalarında aşağıdaki verilen parametreler ve 3621 sayılı Kiy1 Kanununda belirtilen hususlar dikkate alınarak kıyı kenar çizgisinin geçerliliğinin uygun olup olmadığ 1 incelenmiştir. Çalışma alanında yapılan gözlemler ve jeolojik, jeomorfolojik ve jeoteknik açıdan kritik olan noktalardan alınan zemin örnekleri zemin mekaniği laboratuvarında incelenmiştir. Zeminlerin Birleştirilmiş Zemin Sınıflamasına göre SM-SC grubunda, iyi derecelenmiş ve denizel orijinli kumlar olduğu tespit edilmiştir. Acısu Deresi'nin güney ve kuzey sahilinin “alçakbasık kıyı" niteliğinde olduğu, deniz ve denizden sonra plaj platformu oluşturduğu belirlenmiştir. Ancak derenin özellikle kuzey kısmında ve güney kısmının belirli yerlerinde istinat duvarları örülerek su hareketleri engellenmiştir. Arazi çalışmalarından elde edilen parametreler ve 3621 sayılı Kıyı Kanununda belirtilen hususlar dikkate alınarak, 28.06.2010 tarihli Kıy1 Kenar Çizgisi iptal edilerek, 31.08.2008 tarihinde onaylanan kıyı kenar çizgisinin özel konumundan dolayı geçerliliğinin uygun olduğu sonucuna varılmıştır. Tüm bunlarla birlikte Belek kıyı alanının aşırı derecede zorlanarak doğal dengesinin erozyona uğradığ1 görülmüştür.

\section{KATKI BELIRTME}

Yazar makalenin geliştirilmesindeki değerli katkılarından dolayı hakemlere teşekkürlerini sunar.

\section{EXTENDED SUMMARY}

Antalya coast, which is approximately $640 \mathrm{~km}$ long, has been one of the most important tourism areas in Turkey. The coastal area has been destroyed rapidly because of the construction. Belek coasts constitute a good habitat for flora and fauna types due to its micro climatic features that also give rise to a very attractive holiday and rest place. In addition Belek coast, were shaped with coastal dunes of about $29 \mathrm{~km}$ littoral area. It's quite rich in natural life way and as a little living environment. With increase in tourism activity makes Belek coast to become very striking. According to coast law between shoreline and coastal edge is what's called a coast. Recently, to benefit much from coast area human origin has been intervened. In this type of area, redefining form another different shoreline. This study was prepared to emphasize the importance of the shoreline. The specific position of the Coastline Line, which has examined the coastal use of the land part between Acisu Stream and the Mediterranean coast, has been revealed. Especially, it seems that Acisu Creek bed plays an important role in shaping the coast. For this reason, the coastal zone and the parts of the sea are taken into consideration. Geological, geomorphological and geotechnical investigations were carried out. In addition to lithological observations, features such as topography, geomorphological and soil formation and plant development of the site have been taken into consideration in the examinations made. The parameters obtained from the field studies and the issues specified in the Coastal Law No. 3621 are taken into consideration. The Coastal Edge Line dated 28.06.2010 was canceled and it was concluded that the validity of the coastal line approved on 31.08.2008 was appropriate due to its special position. According to Article 4 of the Regulation on the Implementation of the Coastal Law, it is necessary to determine the shoreline in the rivers. With all of this, the coastal area of Belek has been struggling extensively and natural 
deforestation has been undergoing erosion. With all of this, the coastal area of Belek has been struggling extensively and natural deforestation has been undergoing erosion.

\section{DEĞİNILEN BELGELER}

Akay, E., Uysal, S., Poisson, A., Cravatte C.F.P.J. ve Müler, C., 1985a. Antalya Neojen havzasının stratiğrafisi. Türkiye Jeoloji Kurumu Bülteni, 28, 105-119.

Akay, E., Uysal, S., 1985b. Orta Torosların batısındaki (Antalya) neojen çökellerinin stratigrafisi, sedimentolojisi ve yapısal jeolojisi. MTA Rap. No: 7799.

Alpar, B., Doğan, E., Yüce, H. ve Altık, H., 2000. Seal level changes along the Turkish coasts of the Black Sea, the Aegean Sea and the Eastern Mediterranean. Mediterranean, Marine Science, 1, 141-156.

Bellomo, D., Pajak, M.J. ve Sparks, M.J., 1999. Coastal flood hazards and the National Flood Insurance Program. Journal of Coastal Research, Special Issue 28, 21-26.

Boak E.H. ve Turner I.L., 2005. Shoreline definition and detection: A Review. Journal of Coastal Research, 21(4), 688-703.

Coastal Engineering Research Center., 1984. Shore protection manual, Volumes 1 and 2. Washington, DC: US Army Corps of Engineers, Waterways Experiment Station, Coastal Engineering Research Center.

Çelik, K., 2015. Kıyı alanlarının planlanmasında kıyı kenar çizgisinin önemi. Küresel Mühendislik Çalışmaları Dergisi, 2(1), 36-43.

Çiçek, İ., Türkoglu, N. ve Gürgen, G., 2008. Karpuz Çay deltasının (Antalya Doğusu) Paleojeomorfolojisi. Coğrafi Bilimler Dergisi, 6(1), 22-39.

Dolan, R., Fenster, M.S. ve Holme, S.J., 1991. Temporal analysis of shoreline recession and accretion. Journal of Coastal Research, 7(3), 723-744.

Douglas, B.C., Crowell, M. ve Leatherman, S.P., 1998. Considerations for shoreline position prediction. Journal of Coastal Research, 14(3), 1025-1033.

Douglas, B.C.ve Crowell, M., 2000. Long-term shoreline position prediction and error propagation. Journal of Coastal Research, 16(1), 145-152.
Eryılmaz, M. ve Yücesoy Eryılmaz F., 2002. Antalya Körfezi`nin Oşinografi yapısı ve güncel çökel dağılımı. 55 Türkiye Jeoloji Kurultayı, Bildiri Özleri, 88-90.

Ferudun, A., 2009. Kıyı alanlarının hukuki statüsü. Journal of Naval Science and Engineering, 5(1), 76-93.

Glover, C.P. ve Robertson, H.F., 1998. Role of regional extention and uplift in the Plio-Pleistocene evolution of the Aksu Basin, SW Turkey. Journal of the Geological Society, 155, 365-387.

Hanson, H., Gravens, M.B. ve Kraus, N.C., 1988. Prototype applications of a generalized shoreline change numerical model. Proceedings of the 21st International Conference on Coastal Engineering (Costa del Sol-Malaga, Spain), 1265-1279.

İnam, E.A., 2009. Sürdürülebilir turizm bağlamında yöre imgesi: Antalya -Belek Turizm Merkezi Örneği, Yıldız Teknik Üniversitesi, Fen Bilimleri Enstitüsü, Mimarlık Anabilim Dalı, Doktora Tezi, $231 \mathrm{~s}$

Kaman, H., Sönmez, N.K., Çetin, M., Kurunç, A., Aslan, G.E. ve Uz, B.Y., 2011. Denizle irtibatl akarsularda deniz suyu girişiminin irdelenmesi: Antalya Acısu Deresi Örneği. Tarım Bilimleri Araştırma Dergisi, 4(2), 43-47.

Koç, K., Koşun, E. ve Karaman, M.E., 2015. Kıyı sedimentlerinde tane boyunu etkileyen faktörler: Antalya Körfezi’nde Konyaaltı ve Lara Plajlarının (Antalya) Karşılaştırılması. Türkiye Jeoloji Bülteni, Cilt 58, Sayı 2, 85-102.

Komar, P.D., 1998. Beach Processes and Sedimentation. Upper Saddle River, New Jersey: Prentice Hall Inc., $544 \mathrm{~s}$.

Leatherman, S.P., 2001. Social and economic costs of sea level rise. In: Douglas, B.C., Kearney, M.S., and Leatherman, S.P. (eds.), Sea Level Rise History and Consequences. San Diego, California: Academic Press, p.232.

Moore, L.J., 2000. Shoreline mapping techniques. Journal of Coastal Research, 16(1), 111-124.

Morton, R.A. ve Speed, F.M., 1998. Evaluation of shorelines and legal boundaries controlled by water levels on sandy beaches. Journal of Coastal Research, 14(4), 1373-1384.

National Research Council, 1990. Managing Coastal Erosion. Washington, DC: National Academy Press, $182 \mathrm{~s}$. 
Numanoğlu Genç A., 2016. Alara, Türkiye denizel alanında sediman taşınımının modellenmesi. Journal of the Faculty of Engineering and Architecture of Gazi University, 31(3), 545-553.

Özyurt, G., 2012. Yapı denetimi hakkında kanun ve bazı kanunlarda değiş̧iklik taslağı 'Kıyı Kanunu'nu nasıl etkiliyor? İMO Kıyı ve Deniz Mühendisliği Çalışma Grubu, TMH - 474 - 2012/4, 24-28.

Sayan, S., 1999. Antalya kıyılarındaki turistik tesisler ile çevre arasındaki ilişkilerin peyzaj mimarlığı yönünden değerlendirilmesi, Anatolia: Turizm Araştırmaları Dergisi, yıl 11, Mart-Haziran, 1420.

Smith, A.W.S. ve Jackson, L.A., 1992. The variability in width of the visible beach. Shore and Beach, 60(2), p.7-14
TC Resmi Gazete., (1990), 3621 sayılı Kıyı Kanunu, http://mevzuat.basbakanlik.gov.tr

Turoğlu, H., 2009. 3621 Sayılı Kıyı Kanunun ve Onun Uygulama Problemleri. Türk Coğrafya Dergisi, 53, 31-40.

Tziperman, E. ve Malonette-Rizzoli, P., 1991. The climatological seasonal circulation of the Mediterranean Sea. Journal of Marine Research, 49, 411-434.

ETS Turizm, http://www.etstur.com/ Xanadu Resort Hotel, Erişim Tarihi: 11.01.2017.

ETS Turizm, http://www.etstur.com/ Gloria-SerenityResort, Erişim Tarihi: 11.01.2017. 